\title{
PENERAPAN MODEL PEMBELAJARAN KOOPERATIF TIPE JIGSAW IV UNTUK MENINGKATKAN HASIL BELAJAR PKN SISWA KELAS X IPA.4 SMA NEGERI 9 PEKANBARU
}

\author{
(Application of Cooperative Learning Model of Jigsaw IV Type to Improve PKN Learning \\ Outcomes of Class X IPA.4 Students of SMA Negeri 9 Pekanbaru)
}

\author{
Oleh: Suhada Hamsi \\ No HP :081371503418
}

*) Guru Pendidikan Kewarganegaraan SMA Negeri 9 Pekanbaru

\begin{abstract}
This study aims to determine the application of the Jigsaw IV learning model can improve PKn learning outcomes of students of class X IPA.4 Pekanbaru 9 High School. As the subjects in this study were class X IPA.4 Pekanbaru 9 High School 2017/2018 Academic Year which amounted to 38 students. The measured variable is the Jigsaw IV learning model can improve PKn learning outcomes, student learning outcomes obtained through observation sheets of teacher activity, observation of student activities and student learning outcomes. Based on the results of research that has been done, it was found an increase in PKn learning outcomes of students from the learning outcomes obtained by students, using the application of the Jigsaw IV learning model can improve PKn learning outcomes, which carried out 2 cycles, in the first cycle in the application of Students' Jigsaw IV learning model the target is 29 students or $76 \%$, while in cycle 2 there is an increase of 32 students or $84 \%$ stated to meet the KKM standard, only 16\% are declared incomplete or as many as 6 people. The application of IV jigsaw learning model can improve student learning outcomes.
\end{abstract}

Keywords: Learning Model, Cooperative, Jigsaw IV Type, and Learning Outcomes.

\section{PENDAHULUAN}

Upaya memperbaiki dan meningkatkan mutu pendidikan seakan tidak pernah berhenti. Banyak agenda reformasi yang telah, sedang, dan akan dilaksanakan. Reformasi pendidikan adalah restrukturisasi pendidikan, yakni memperbaiki pola hubungan sekolah dengan lingkungannya dan dengan pemerintah, pola pengembangan perencanaan, serta pola pengembangan manajerialnya, pemberdayaan guru dan restrukturisasi model model pembelajaran.Reformasi pendidikan tidak cukup hanya dengan perubahan dalam sektor kurikulum, baik struktur maupun prosedur penulisannya. Pembaharuan kurikulum akan lebih bermakna bila diikuti oleh perubahan praktik pembelajaran di dalam maupun di luar kelas. Keberhasilan implementasi kurikulum sangat dipengaruhi oleh kemampuan guru yang akan menerapkan dan mengaktualisasikan kurikulum tersebut. Tidak jarang kegagalan implementasi kurikulum disebabkan oleh kurangnya pengetahuan, keterampilan dan kemampuan guru dalam memahami tugas tugas yang harus dilaksanakannya. Hal itu berarti bahwa guru sebagai pelaksana kegiatan pembelajaran menjadi kunci atas keterlaksanaan kurikulum di sekolah.

Dalam kurikulum 2004, guru diberi kebebasan untuk mengubah, memodifikasi, bahkan membuat sendiri silabus yang sesuai dengan kondisi sekolah dan daerahnya, dan menjabarkannya menjadi persiapan mengajar yang siap dijadikan 
pedoman pembentukan kompetensi peserta didik.Menurut Undang-Undang Guru pasal 1 ayat 1 (2006:3) guru adalah pendidik profesional dengan tugas utama: mendidik, mengajar, membimbing, mengarahkan, melatih, menilai, dan mengevaluasi peserta didik pada pendidikan anak usia dini jalur pendidikan formal, pendidikan dasar dan pendidikan menengah. Dalam rangka meningkatkan mutu pendidikan di Indonesia, pemerintah telah menetapkan Undang-Undang Sistem Pendidikan. Undang-Undang tersebut memuat dua puluh dua bab, tujuh puluh tujuh pasal dan penjelasannya. Undang-undang Sistem Pendidikan (2003:37) menjelaskan bahwa setiap pembaruhan sistem pendidikan nasional untuk memperbarui visi, misi dan strategi pembangunan pendidikan nasional. Visi pendidikan nasional di antaranya adalah (1) mengupayakan perluasan dan pemerataan kesempatan memperoleh pendidikan yang bermutu bagi seluruh rakyat Indonesia, (2) membantu dan memfasilitasi pengembangan potensi anak bangsa secara utuh sejak usia dini sampai akhir hayat dalam rangka mewujudkan masyarakat belajar, (3) meningkatkan kesiapan masukan dan kualitas proses pendidikan untuk mengoptimalkan pembentukan kepribadian yang bermoral, (4) meningkatkan keprofesionalan dan akuntabilitas lembaga pendidikan sebagai pusat pembudayaan ilmu pengetahuan, keterampilan, pengalaman, sikap, dan nilai berdasarkan standar nasional dan global, (5) Memperdayakan peran sertamasyarakat dalam penyelenggaraan pendidikan berdasarkan prinsip otonomi dalam konteks Negara Kesatuan RI.

Jika mencermati visi pendidikan tersebut, semuanya mengarah pada mutu pendidikan yang akhirnya dapat meningkatkan hasil belajar peserta didik. Mutu pendidikan ternyata dipengaruhi oleh banyak komponen. Menurut Syamsuddin (2005:66) ada tiga komponen utama yang saling berkaitan dan memiliki kedudukan strategis dalam kegiatan belajar mengajar. Ketiga komponen tersebut adalah kurikulum, guru, dan pembelajar (siswa). Ketiga komponen itu, guru menduduki posisi sentral sebab peranannya sangat menentukan. Dalam pembelajaran seorang guru harus mampu menerjemahkan nilainilai yang terdapat dalam kurikulum secara optimal. Walaupun sistem pembelajaran sekarang sudah tidak theacher center lagi, namun seorang guru tetap memegang peranan yang penting dalam membimbing siswa. Bahkan berdasarkan seorang guru harus mempunyai pengetahuan yang memadai baik di bidang akademik maupun pedagogik. Menurut Djazuli (1886:2) seorang guru dituntut memiliki wawasan yang berhubungan dengan mata pelajaran yang diajarkannya dan wawasan yang berhubungan kependidikan untuk menyampaikan isi pengajaran kepada siswa. Kedua wawasan tersebut merupakan satu kesatuan yang tidak dapat dipisahkan. Seorang guru harus selalu meningkatkan kemampuan profesionalnya, pengetahuan, sikap dan keterampilannya secara terusmenerus sesuai perkembangan ilmu pengetahuan dan teknologi termasuk paradigma baru pendidikan. Menurut Dirjen Pendidikan Dasar dan Menengah DepartemanPendidikan Nasional (2004:2) seorang guru harus memenuhi tiga standar kompetensi, di antaranya: (1) Kompetensi Pengelolaan Pembelajaran dan Wawasan Kependidikan, (2) Kompetensi Akademik/Vokasional sesuai materi pembelajaran, (3) Pengembangan Profesi. Ketiga kompetensi tersebut bertujuan agar guru bermutu, menjadikan pembelajaran bermutu juga, yang akhirnya meningkatkan mutu pendidikan Indonesia. Siswa atau anak didik adalah salah satu komponen manusiawi yang menempati posisi sentral dalam proses belajar mengajar. Di dalam proses belajar mengajar, siswa sebagai pihak yang ingin meraih cita-cita, memiliki tujuan dan kemudian ingin mencapainya secara optimal. Siswa atau anak didik itu akan menjadi faktor penentu, sehingga menuntut dan dapat mempengaruhi segala sesuatu yang diperlukan untuk mencapai tujuan 
belajarnya. Jadi dalam proses belajar mengajar yang diperhatikan pertama kali adalah siswa atau anak didik, bagaimana keadaan dan kemampuannya, baru setelah itu menetukan komponen-komponen yang lain. Apa bahan yang diperlukan, bagaimana cara yang tepat untuk bertindak, alat dan fasilitas apa yang cocok dan mendukung, semua itu harus disesuaikan dengan keadaan/karakteristik siswa. Itulah sebabnya siswa atau anak didik adalah merupakan subjek belajar.

Guru memegang peranan yang amat penting dan strategis dalam proses pembelajaran, maka seorang guru harus kreatif dalam menemukan hal-hal baru untuk mencapai hasil pembelajaran yang optimal. Jajaran pengelola pendidikan, baik instansi yang membawahi sekolah, maupun guru sebagai pelaksana lapangan pendidikan, diharapkan mampu mewujudkan tujuan minimal standar pendidikan nasional yaitu membentuk manusia berkualitas yang beriman dan bertaqwa kepada Tuhan Yang Maha Esa.

Permasalahan yang berkenaan dengan siswa di kelas, jika tidak dicari solusi dan dibiarkan berlalu begitu saja, akan lebih kompleks dan berlarut-larut. Akibatnya, akan dirasakan pada ketidak-kompetenan siswa dimasyarakat yang berhubungan dengan materi pelajaran. Permasalahan siswa maupun guru selama proses belajar, menjadi prioritas, untuk secepatnya diteliti penyebab dan solusinya. Hal itu perlu dipahami oleh seorang guru, karena keberhasilan belajar siswa ditentukan, sejauh mana guru memiliki inisiatif perbaikan terhadap prosedur dan hal yang berkaitan dengan proses yang telah dilakukan.

Berdasarkan hasil pengamatan selama peneliti bertugas di SMA Negeri 9 Pekanbaruditemui gejala-gejala atau fenomena khususnya pada pelajaran PKn kelas X IPA.4sebagai berikut:

1. Dari 38 siswa terdapat 20 siswa atau $53 \%$ yang memperoleh hasil belajar $\leq \mathrm{kkm}$.

2. Anak kurang aktif dalam mata pelajaran yang disajikan, hal ini terlihat pada saat dilakukan session Tanya jawab hanya beberapa orang yang aktif.

3. Siswa merasa sulit memahami pelajaran dikarenakan anggapan bahwasannya mata pelajaran PKn cukup rumit untuk dipelajari..

Dari fenomena-fenomena atau gejalagejala tersebut di atas, terlihat bahwa pembelajaran yang dilaksanakan oleh guru khususnya pada bidang studi PKn kurang memberikan hasil yang diharapkan. Oleh sebab itu peneliti tertarik ingin melakukan suatu penelitian tindakan sebagai upaya dalam melakukan perbaikan terhadap pembelajaran dengan judul "Penerapan model pembelajaran kooperatif tipe jigsaw IV untuk Meningkatkan Hasil Belajar PKn Siswa Kelas X IPA.4 SMA Negeri 9 Pekanbaru" dengan Rumusan masalah dalam penelitian ini adalah Apakah dengan Penerapan model pembelajaran Jigsaw IV dapat meningkatkan hasil belajar PKn siswa kelas X IPA.4 SMA Negeri 9 Pekanbaru?. Adapun yang manjadi tujuan dalam penelitian ini adalah untuk mengetahui hasil belajar PKn siswa kelas X IPA.4 SMA Negeri 9 Pekanbaru.

\section{Pengertian Model Pembelajaran Kooperatif}

Tipe jigsaw dikembangkan oleh Elliot dan kawan-kawannya dari Universitas Texas dan kemudian diadaptasi oleh Slavin dan kawan-kawannya.Kunandar

mengemukakan langkah-langkah tipe Jigsaw adalah sebagai berikut:

1. Kelompok kooperatif awal : 1) Siswa dibagi kedalam kelompok kecil 3-6 siswa. 2) Bagian wacana atau tugas akademik yang sesuai dengan materi yang diajarkan..3) Masing-masing siswa dalam kelompok mendapatkan wacana atau tugas yang berbeda-beda dan memahami informasi yang ada di dalamnya.

2. Kelompok Ahli : a) Kumpulan masing-masing siswa yang memiliki wacana atau tugas yang sama dalam 
satu kelompok sehingga jumlah kelompok ahli sesuai dengan wacana atau tugas yang telah dipersiapkan oleh guru. b) Dalam kelompok ahli ini ditugaskan agar siswa belajar bersama untuk menjadi ahli sesuai dengan wacana atau tugas yang menjadi tanggung jawabnya. c) Tugaskan bagi semua anggota kelompok ahli untuk memahami dan dapat menyampaikan informasi tentang hasil dari wacana atau tugas yang telah dipahami kepada kelompok kooperatif ( kelompok awal). d) Apabila tugas sudah selesai dikerjakan dalam kelompok ahli masing-masing siswa kembali ke kelompok kooperatif ( kelompok awal). e) Beri kesempatan secara bergiliran masing-masing siswa untuk menyampaikan hasil dari tugas di kelompok ahli. f) Apabila kelompok sudah menyelesaikan tugasnya, secara keseluruhan masing-masing kelompok melaporkan hasilnya dan guru memberi klarifikasi. Kunandar (2007:343)

Menurut Bolen (dalam Maria Ernawati, 2006:14) menyatakan ada beberapa tipe pembelajaran tipe Jigsaw, antara lain :tipe jigsaw I, Jigsaw II, Jigsaw IV dan Jigsaw IV.

Karakteristik Pembelajaran Kooperatif Tipe Jigsaw

\begin{tabular}{llll}
\hline $\begin{array}{l}\text { N } \\
\text { o }\end{array}$ & Jigsaw II & Jigsaw III & Jigsaw IV \\
\hline 1 & Tahap & Tahap & Tahap \\
& pendahulua & pendahulua & pendahulua \\
& n & n & n \\
\hline 2 & membagik & membagik & membagik \\
& an lembar & an lembar & an lembar \\
& latihan & latihan & latihan \\
& kepada tim & kepada tim & kepada tim \\
& ahli & ahli & ahli \\
\hline 3 & Tim & Tim & Tim \\
& menjawab & menjawab & menjawab \\
& pertanyaan & pertanyaan & pertanyaan \\
& yang & yang & yang \\
& diajukan & diajukan & diajukan \\
& oleh tim & oleh tim & oleh tim \\
ahli dan & ahli dan & ahli dan \\
\hline
\end{tabular}

\begin{tabular}{|c|c|c|c|}
\hline & $\begin{array}{l}\text { mempriorit } \\
\text { askan } \\
\text { untuk } \\
\text { dikerjakan } \\
\text { bersama } \\
\text { kelompok }\end{array}$ & $\begin{array}{l}\text { mempriorit } \\
\text { askan } \\
\text { untuk } \\
\text { dikerjakan } \\
\text { bersama } \\
\text { kelompok }\end{array}$ & $\begin{array}{l}\text { mempriorit } \\
\text { askan } \\
\text { untuk } \\
\text { dikerjakan } \\
\text { bersama } \\
\text { anggota } \\
\text { kelompok }\end{array}$ \\
\hline 4 & & & $\begin{array}{l}\text { Materi } \\
\text { kuis/latiha } \\
\mathrm{n} \\
\text { didiskusika } \\
\mathrm{n} \text { bersama } \\
\text { untuk } \\
\text { menganalis } \\
\text { a } \\
\text { kebenarann } \\
\text { ya jawaban }\end{array}$ \\
\hline 5 & $\begin{array}{l}\text { Siswa } \\
\text { kembali } \\
\text { dan } \\
\text { mendiskusi } \\
\text { kan } \\
\text { informasi } \\
\text { dengan } \\
\text { teman } \\
\text { setim }\end{array}$ & $\begin{array}{l}\text { Siswa } \\
\text { kembali } \\
\text { dan } \\
\text { mendiskusi } \\
\text { kan } \\
\text { informasi } \\
\text { dengan } \\
\text { teman } \\
\text { setim }\end{array}$ & $\begin{array}{l}\text { Siswa } \\
\text { kembali } \\
\text { dan } \\
\text { mendiskusi } \\
\text { kan } \\
\text { informasi } \\
\text { dengan } \\
\text { teman } \\
\text { sekelompo } \\
\text { k }\end{array}$ \\
\hline 6 & & & $\begin{array}{l}\text { Kuis/latiha } \\
\mathrm{n} \text { dalam } \\
\text { materi } \\
\text { diperiksa } \\
\text { kebenarann } \\
\text { ya }\end{array}$ \\
\hline 7 & & $\begin{array}{l}\text { Proses } \\
\text { peninjauan } \\
\text { oleh semua } \\
\text { tim }\end{array}$ & $\begin{array}{l}\text { Proses } \\
\text { peninjauan } \\
\text { oleh semua } \\
\text { tim }\end{array}$ \\
\hline 8 & Latihan & Latihan & Latihan \\
\hline & $\begin{array}{l}\text { ngertian Has } \\
\text { enurut Gagn } \\
\text { ajiono, 2000 } \\
\text { giatan ya } \\
\text { nghasilkan p } \\
\text { n sikap. } \\
\text { ormasi yang } \\
\text { langkan ket } \\
\text { dakan atau t } \\
\text { erlihatkan } \\
\text { hwa orang t } \\
\text { alah kemar }\end{array}$ & $\begin{array}{l}\text { I Belajar } \\
\text { (dalam D } \\
\text { 10) "Belajar } \\
\mathrm{g} \text { komple } \\
\text { ngetahuan, k } \\
\text { engetahuan } \\
\text { tersimpan da } \\
\text { rampilan as } \\
\text { akkah laku } \\
\text { eseorang sel } \\
\text { rsebut memil } \\
\text { puan men }\end{array}$ & $\begin{array}{l}\text { imyati dan } \\
\text { merupakan } \\
\text { ks yang } \\
\text { eterampilan, } \\
\text { membentuk } \\
\text { lam pikiran, } \\
\text { lalah suatu } \\
\text { ang mampu } \\
\text { agai tanda } \\
\text { ikinya.Sikap } \\
\text { rima atau }\end{array}$ \\
\hline
\end{tabular}


menolak objek berdasarkan penilaian terhadap objek tersebut". Slameto (2003:2) mendefenisikan bahwa belajar adalah suatu proses usaha yang dilakukan seseorang untuk memperoleh suatu perubahan tingkah laku yang baru secara keseluruhan, sebagai hasil pengalamannya sendiri dalam interaksi dengan lingkungannya.

Dalam kegiatan belajar terjadi perubahan perilaku, sebagaimana dikemukakan oleh Dimyati dan Mudjiono (2000:7) bahwa belajar merupakan suatu proses internal yang kompleks, yang terlibat dalam proses internal tersebut adalah yang meliputi unsur afektif, dalam matra afektif berkaitan dengan sikap, nilai-nilai, interes, apresiasi, dan penyesuaian perasaan sosial. Djamarah (2002:13) bahwa Seseorang yang sedang belajar berarti ia melakukan suatu aktivitas atau kegiatan yang dilakukan yang melibatkan dua unsur yaitu jiwa dan raganya. Gerak raga yang ditunjukkan harus sejalan dengan proses jiwa untuk mendapatkan perubahan. Tentu saja perubahan yang didapatkan itu bukan perubahan fisik, tetapi perubahan jiwa sebab masuknya kesan-kesan baru. Sedangkan Menurut Oemar Hamalik (2004:27) belajar adalah modifikasi atau memperteguh kelakuan melalui pengalaman. Menurut pengertian ini, belajar merupakan suatu proses, suatu kegiatan dan bukan suatu hasil atau tujuan. Belajar bukan hanya mengingat, akan tetapi lebih luas dari itu, yakni mengalami. Hasil belajar bukan suatu penguasaan hasil latihan melainkan pengubahan kelakuan.Dari definisi-definisi di atas dapat disimpulkan bahwa belajar merupakan segenap rangkaian kegiatan atau aktivitas yang dilakukan secara sadar oleh seseorang dan mengakibatkan perubahan dalam dirinya berupa penambahan pengetahuan atau kemahiran berdasarkan alat indera dan pengalamannya.Oleh sebab itu apabila setelah belajar peserta didik tidak ada perubahan tingkah laku yang positif dalam arti tidak memiliki kecakapan baru serta wawasan pengetahuannya tidak bertambah maka dapat dikatakan bahwa belajarnya belum sempurna.

\section{METODE PENELITIAN}

Penelitian ini merupakan penelitian tindakan kelas yang dilaksanakan di kelas X IPA.4 SMA Negeri 9 Pekanbaru Tahun Pelajaran 2017/2018 dengan jumlah siswa 38 orang. Penelitian ini dilakukan selama 2 bulan dengan dua siklus yang dimulai dari tanggal 6 februari sampai 10 april 2018. Subjek yang diteliti adalah siswa kelas $\mathrm{X}$ IPA.4 SMA Negeri 9 Pekanbaru Tahun Pelajaran 2017/2018 dengan jumlah siswa sebanyak 38 orang, karakteristiknya adalah kira-kira $47 \%$ di bawah nilai kriteria ketuntasan minimal (KKM) yang ditetapkan sekolah.

\section{HASIL PENELITIAN \\ Siklus Pertama \\ Rencana}

Tindakan siklus I dilaksanakan pada tanggal 6 Februari 2018 dan ulangan harian siklus 1 pada tanggal 13Februari 2017. Jadwal penelitian ini sesuai dengan jadwal pembelajaran yang telah ditetapkan di SMA Negeri 9 Pekanbaru.Standar kompetensi dalam penelitian ini adalah Menganalisis hubungan internasional dan organisasi internasional. Tahapan-tahapan dalam pelaksanaan tindakan kelas yang menggunakan Model Pembelajaran Kooperatif Tipe Jigsaw IV. Perbaikan proses pembelajaran dengan menerapkan Model Pembelajaran Kooperatif Tipe Jigsaw IV dalam siklus pertama dikelola berdasarkan Rencana Pelaksanaan Pembelajaan (RPP). Berdasarkan hasil pengamatan observer, dalam penerapan ModelPembelajaran Kooperatif Tipe Jigsaw IVpada siklus I atau terdiri dari 1 kali pertemuan, diperoleh hasil bahwa skor yang diperoleh guru dalam pelaksanaan Model Pembelajaran Kooperatif Tipe Jigsaw IV , setelah dibandingkan dengan standar klasifikasi yang telah ditetapkan. Aktivitas guru pada siklus I ini berada pada klasifikasi "cukup 
sempurna" karena skor rata-rata 25 berada pada interval 20,9 - 27,2 dengan kategori cukup sempurna. Permasalahan yang hadir dalam aktivitas guru pada siklus I disebabkan model yang digunakan dalam proses pembelajaran ini masih kurang dipahami oleh siswa, sehingga menyulitkan guru dalam melaksanakan proses pembelajaran yang diharapkan.

Perbaikan proses pembelajaran dengan menerapkan metode kooperatif tipe jigsaw IV pada siklus pertama dikelola berdasarkan Rencana Pelaksanaan Pembelajaran (RPP 1). Dalam melaksanakan tindakan yang direncanakan ternyata belum sepenuhnya dapat direalisasikan. Guru berusaha agar siswa memahami materi.Siswa yang berkemampuan sedang dan rendah tidak ada kemauan untuk aktif dan bertanya terhadap materi pelajaran jika kurang dipahami. Dan pada akhirnya hanya siswa yang pandai dan berani saja yang aktif dalam proses belajar mengajar. Hal ini mengakibatkan rasa rendah diri pada siswa yang berkemampuan rendah dan sikap cuek pada siswa yang berkemampuan sedang.

Berdasarkan analisis data diperoleh ratarata aktivitas siswa secara umum berklasifikasi "Rendah", karena 152 berada pada rank 77-152dengan kategori rendah. Setelah kegiatan pembelajaran selesai dilaksanakan, maka dilakukan evaluasi terhadap materi pelajaran.Setelah evaluasi pembelajaran selesai dilaksanakan, maka akan diperoleh hasil pembelajaran yang telah dijalani siswa, yaitu dengan Model Pembelajaran Kooperatif Tipe Jigsaw IV .Hasil belajar siswa pada siklus pertama menunjukkan dari 38 orang siswa terdapat 9 orang siswa atau sebesar $24 \%$ siswa yang belum tuntas atau nilai dibawah KKM, sisanya 29 siswa atau $76 \%$ siswa yang tuntas. Dengan perolehan rata-rata nilai keseluruhan siswa sebesar 71,84 dengan klasifikasi tinggi dalam rentang interval 71-85. Sebelum diterapkannya Model Pembelajaran Kooperatif Tipe Jigsaw IV diketahui bahwa siswa yang memperoleh nilai dibawah kriteria ketuntasan minimal (KKM) sebesar $75 \%$ pada siklus pertama setelah diterapkannya Model Pembelajaran Kooperatif Tipe JIGSAW I , siswa yang belum tuntas sebesar $23,68 \%$ atau terdapat 9 orang siswa yang belum mencapai ketuntasan klasikal yakni nilai 75 seperti yang telah ditetapkan di SMA Negeri 9 Pekanbaru.

Sesuai hasil pembahasan peneliti dan pengamat terhadap perbaikan pembelajaran pada siklus pertama, maka diperoleh beberapa kekuatan dan kelemahan pembelajaran diantaranya:

a. Pengelolaan pembelajaran oleh peneliti telah sesuai dengan tahapan yang dimuat dalam RPP. Namun penerapan Model Pembelajaran Kooperatif Tipe Jigsaw IV dalam proses pembelajaran, peneliti masih mengalami beberapa kelemahan khususnya pada aktivitas penjelasan tentang Model Kooperatif Tipe Jigsaw IV, siswa masih belum menangkap jelas penjelasan tentang Model yang akan diterapkan tersebut sehingga prosesnya masih belum tertib,

b. Walaupun secara umum aktivitas siswa dalam proses pembelajaran dikategorikan rendah, Sehingga masih memerlukan banyak perhatian untuk tiap aspek aktivitas yang diamati.

c. Sedangkan hasil belajar siswa sudah menunjukkan bahwa secara rata-rata nilai keseluruhn siswa mencapai ketuntasan kelas yaitu sebesar dengan kategori tinggi, dengan persentase siswa tuntas sebesar $34,21 \%$ dan , siswa yang belum mencapai ketuntasan klasikal sebesar $65,79 \%$ atau masih terdapat 25 siswa dari 38 siswa yang hasil belajarnya masih di bawah nilai KKM 75.

Berdasarkan penjelasan pada refleksi, maka perlu diadakan perbaikan pada siklus berikutnya agar tingkat siswa yang belum mencapai KKM dapat ditingkatkan melalui model pembelajaran Kooperatif Tipe Jigsaw Tipe IV. Kekurangan yang perlu diatasi dari siklus pertama adalah: (1) 
menyajikan materi sebaik mungkin, sehingga mudah dimengerti oleh siswa (2) menampilkan sebuah poster yang berkaitan dengan materi pelajaran. (3) memberikan stimulus kepada siswa dala menyimpulkan isi dan pesan materi yang dibahas dengan memberikan contoh yang relevan agar memancing reaksi siswa untuk dapat megambil kesimpulan materi pelajaran.

\section{Siklus Kedua}

Berdasarkan refleksi pada siklus I ditemui bahwa proses pembelajaran PKn dengan Model Kooperatif Tipe Jigsaw IV sudah memberikan hasil yang baik untuk hasil belajar. Agar hasil belajar siswa maka perlu dirancang suatu tindakan untuk dilaksanakan pada siklus kedua. Tindakan pada siklus kedua dimaksudkan untuk memperbaiki tindakan pada siklus I. Tindakan utama pada siklus I tetap dilaksanakan pada siklus II yaitu penerapan Model Pembelajaran Kooperatif Tipe Jigsaw IV .Waktu pelaksanaan siklus kedua berlangsung dalam Dua minggu setelah selesainya siklus pertama.Pertemuan pertama dan kedua pada siklus kedua ini berlangsung pada tanggal 13 maret 2018. Lama waktu untuk siklus kedua adalah 2 kali pertemuan, pertemuan pertama untuk pembahasan materi, pertemuan kedua pada tanggal 20 maret 2018 Ulangan Harian.

Proses pembelajaran diawali dengan menjelaskan bagaimana cara mengumpulkan data dengan mencacah, mengukur dan mencacat hasil dengan terus selanjutkan melengkapi LKS, Setelah kegiatan awal selesai dilaksanakan.maka kegiatan pembelajaran dilanjutkan pada kegiatan inti pembelajaran.Setelah kegiatan inti selesai, kegiatan dilanjutkan pada kegiatan akhir pembelajaran dengan memberi stimulus kepada siswa untuk menarik kesimpulan isi materi yang telah dipelajari berama.

Setelah seluruh kegiatan pembelajaran dilaksanakan, maka diperoleh data hasil observasi aktivitas guru dengan Model Kooperatif Tipe Jigsaw IV pada siklus kedua diketahui skor rata-rata yang diperoleh guru dalam pelaksanaan Model Kooperatif Tipe Jigsaw IV, setelah dibandingkan dengan standar klasifikasi yang telah ditetapkan. Aktivitas guru pada siklus II ini berada pada klasifikasi "sangat sempurna" karena skor rata-rata 39 berada pada interval 33,7 - 40 dengan kategori sangat sempurna.Seperti halnya pada siklus pertama, pengamatan didasarkan pada dua hal yaitu; 1) Hasil pengamatan langsung yang dilakukan oleh guru dan teman sejawat untuk mengetahui aktivitas guru dalam penggunaan metode poster comentdan 2) aktivitas siswa selama pembelajaran.Adapun hasil pengamatan pada siklus II menunjukkan peningkatan sangat baik dari aktivitas guru dan aktivitas siswa serta hasil belajar siswa.

Berdasarkan pengamatan observer berkaitan dengan aktivitas siswa siklus II dapat diketahui bahwa skor rata-rata aktivitas siswa pada siklus II adalah 246 berada pada interval 229-304 dengan kategori sangat tinggi.Hal ini dipengaruhi oleh aktivitas guru yang lebih ditingkatkan.Aktivitas guru dalam menggunakan Model Kooperatif Tipe Jigsaw IV. Pada siklus I guru sudah melakukan dengan "cukup sempurna" Sesuai hasil pengamatan dimana aktivitas guru memperoleh skor rata-rata 25 , dan hasil pengamatan aktivitas guru pada siklus II menunjukkan adanya peningkatan dengan skor rata-rata 39 dengan kriteria sangat sempurna.

Hasil belajar pada siklus 2 menunjukkan dari 38 orang siswa 32 siswa atau sebesar $84 \%$ yang memperoleh nilai tuntas atau $\geq$ 75 sedangkan siswa yang belum tuntas atau masih dibawah KKM $\leq 75$ sebanyak 6 orang atau $16 \%$. Hai ini terjadi peningkatan dari siklus 1 yang mana diketahui pada siklus 1 siswa tuntas sebanyak 29 orang siswa atau $76 \%$ dan siswa yang tidak tuntas sebanyak 9 orang dengan persentase 24\%. Dari data tersebut dapat kita lihat terjadi peningkatan siswa tuntas sebesar $8 \%$. Dengan rata-rata nilai keseluruhan sebesar 80 yang mana sebelumnya pada siklus 1 rata-rata hasil 
belajar sebesar 71,84 atau terjadi peningkatan rata-rata nilau ulangan harian sebesar 8,16 point.Oleh karena itu, dapat dikatakan bahwa hasil belajar mata pelajaran PKn pada siklus kedua ini telah mencapai ketuntasan kelas dengan siswa tuntas mencapai $84 \%>\mathrm{KKM}$.

\section{PEMBAHASAN}

Aktivitas guru dalam menggunakan Model Kooperatif Tipe Jigsaw IV, jika pada siklus I guru sudah melakukan dengan "Cukup sempurna". Hal ini sesuai hasil pengamatan dimana aktivitas guru memperoleh skor 25. Hasil pengamatan aktivitas guru pada siklus II menunjukkan adanya peningkatan dengan skor 39 dengan kriteria sangat sempurna. Hal tersebut berdampak positif terhadap aktivitas siswa dalam proses pembelajaran. Pada siklus pertama aktivitas siswa pada siklus I melalui observasi "aktivitas siswa" yang diukur dari 8 komponen (lampiran 7), aktivitas siswa memperoleh skor rata-rata 151 dengan klasifikasi rendah. Sedangkan hasil observasi pada Siklus II aktivitas siswa mencapai skor rata-rata 246 yang tergolong sangat tinggi.

Meningkatnya aktivitas siswa pada siklus kedua berpengaruh terhadap hasil belajar yang diperoleh siswa. Hal tersebut dapat dilihat pada tabel rekapitulasi berikut:

Tabel Rekapitulasi Hasil Belajar Siswa Pada Mata Pelajaran PKn (Siklus 1 dan Siklus 2)

\begin{tabular}{|c|c|c|c|}
\hline \multirow{3}{*}{$\begin{array}{l}\text { Aktivita } \\
\text { s Guru }\end{array}$} & \multicolumn{2}{|l|}{ Siklus 1} & Siklus 2 \\
\hline & Frek & $\%$ & $\begin{array}{l}\text { Fre } \% \\
\mathrm{k}\end{array}$ \\
\hline & 25 & 63 & 97,5 \\
\hline Kategori & \multicolumn{2}{|c|}{$\begin{array}{l}\text { Cukup } \\
\text { Sempurna }\end{array}$} & $\begin{array}{l}\text { Sangat } \\
\text { Sempurna }\end{array}$ \\
\hline \multirow[t]{2}{*}{$\begin{array}{l}\text { Aktivita } \\
\text { s Siswa }\end{array}$} & $\begin{array}{l}\text { Ferwens } \\
\text { i }\end{array}$ & $\%$ & $\begin{array}{l}\text { Fre } \% \\
\mathrm{k}\end{array}$ \\
\hline & 152 & 67,43 & 80,92 \\
\hline Kategori & \multicolumn{2}{|l|}{ Rendah } & $\begin{array}{l}\text { Sangat } \\
\text { Tinggi }\end{array}$ \\
\hline \multirow{2}{*}{$\begin{array}{l}\text { Hasil } \\
\text { Belajar }\end{array}$} & \multicolumn{2}{|l|}{ Siklus 1} & Siklus 2 \\
\hline & Frek & $\%$ & $\begin{array}{l}\text { Fre } \% \\
\mathrm{k}\end{array}$ \\
\hline Siswa & 29 & 76 & 32 \\
\hline
\end{tabular}

\begin{tabular}{lllll}
\hline Tuntas & & & & \\
\hline Siswa & 9 & 24 & 6 & 16 \\
Tidak & & & & \\
Tuntas & & & & \\
\hline Rata- & 71,84 & Tingg & 80 & Tingg \\
Rata & & i & & i \\
Kelas & & & \\
\hline \multicolumn{4}{l}{ Sumber :data olahan tahun 2018}
\end{tabular}

Berdasarkan data pada tabel rekapitulasi, diketahui adanya peningkatan hasil belajar dari siklus pertama ke siklus kedua. Keadaan tersebut menunjukkan bahwa perbaikan pembelajaran pada mata pelajaran PKn dengan menggunakan Model Pembelajaran Kooperatif Tipe Jigsaw IV dapat dikatakan berhasil. Aktivitas guru pada siklus 1 sebelumnya mendapat skor 25 dengan klasifikasi cukup sempurna kemudian pada siklus 2 terjadi peningkatan dengan skor 39 dengan klasifikasi sangat sempurna. Aktivitas Siswa pada siklus I sebelumnya mendapat skor 152 kategori rendah kemudian pada siklus ke 2 mengalami peningkatan yaitu 246 kategori sangat tinggi. Sedangkan hasil belajar pada siklus kedua terlihat bahwa pada siklus 1 siswa tuntas sebesar $76 \%$ atau sebanyak 29 orang siswa dan pada siklus 2 terjadi peningkatan siswa tuntas menjadi $84 \%$ atau sebanyak 32 orang siswa tuntas.

Kelemahan-kelemahan Model Pembelajaran Kooperatif Tipe Jigsaw IV pembelajaran pada siklus pertama setelah diperbaiki pada siklus kedua terbukti dapat meningkatkan hasil belajar siswa. Meningkatnya hasil belajar pada siklus kedua dibandingkan pada siklus pertama menunjukkan bahwa perbaikan pembelajaran yang dibawakan telah dilaksanakan dengan baik dan benar.Artinya, perencanaan pembelajaran yang dibuat sesuai untuk mengatasi permasalahan rendahnya hasil belajar siswa yang terjadi di dalam kelas selama ini. Selanjutnya, adanya peningkatan hasil belajar siswa pada mata pelajaran PKn dari siklus pertama ke siklus kedua menunjukkan bahwa Model Pembelajaran 
Kooperatif Tipe Jigsaw IV dapat meningkatkan hasil belajar PKn siswa Kelas X IPA.4 SMA Negeri 9 Pekanbaru tahun ajaran 2017/2018. Sebagaimana telah dipaparkan sebelumnya bahwa Model Pembelajaran Kooperatif Tipe Jigsaw IV merupakan salah satu metode yang cukup menarik untuk diterapkan agar memicu semangat belajar siswa sehingga menghasilkan hasil belajar yang gemilang. Berdasarkan uraian di atas, dapat disimpulkan bahwa Model Pembelajaran Kooperatif Tipe Jigsaw IV merupakan teknik pembelajaran yang mendorong siswa aktif dan saling membantu dalam menguasai materi pelajaran untuk mencapai prestasi yang maksimal. Dalam metode belajar ini terdapat tahap-tahap dalam penyelenggaraannya. Dengan metode ini, hasil belajar siswa dapat ditingkatkan.

\section{Pengujian Hipotesis}

Dari hasil penelitian dan pembahasan seperti telah diuraikan di atas, menjelaskan bahwa dengan penggunaan Model Kooperatif Tipe Jigsaw IVsecara benar maka aktivitas siswa menjadi lebih meningkat. Informasi ini membuktikan bahwa hipotesis peneliti yang berbunyi "Penerapan Model Pembelajaran Kooperatif Tipe jigsaw IV untuk meningkatkan hasil belajar PKn siswa kelas X IPA.4 SMA Negeri 9 Pekanbaru tahun ajaran 2017-2018"Dapat diterima". Hal ini dapat dilihat padadiagram dan grafik di bawah ini.

Diagram IV.1.

Hubungan Model Pembelajaran Kooperatif Tipe Jigsaw IV dengan Hasil Belajar Siswa

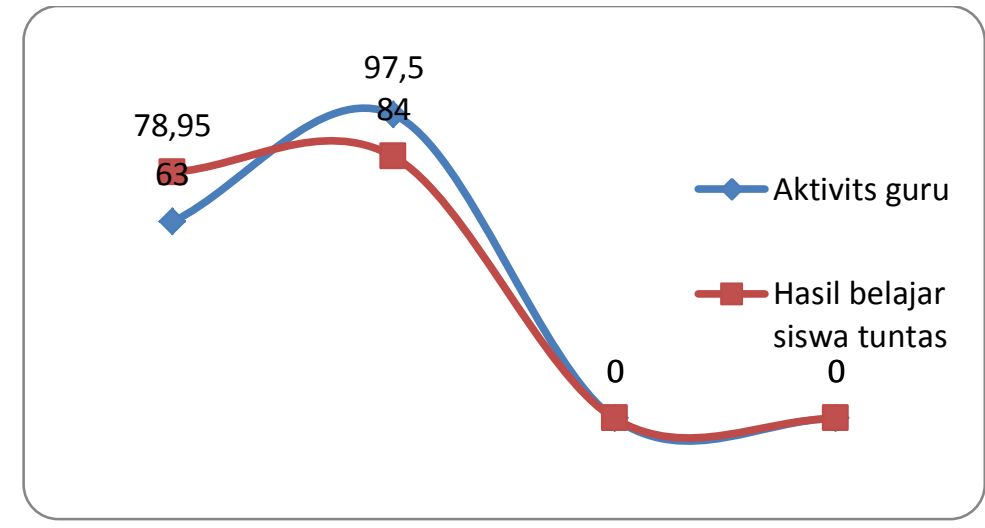

Gafik IV.2. Hubungan Model

Pembelajaran Kooperatif Tipe Jigsaw IV dengan Hasil Belajar Siswa

Dari grafik di atas diketahui rata-rata persentase yang diperoleh guru dalam penerapan Model Pembelajaran Kooperatif Tipe Jigsaw IV pada siklus 1 sebesar $63 \%$, dan siswa tuntas mencapai $76 \%$. Sedangkan pada sikus kedua persentase rata-rata penerapan Model Pembelajaran Kooperatif Tipe Jigsaw IV yang diperoleh guru meningkat sebesar 97,5\%, hal ini berpengaruh positif terhadap hasil belajar siswa dengan siswa tuntas mencapai $84 \%$. Sehingga dapat disimpulkan bahwa penerepan Model Pembelajaran Kooperatif Tipe Jigsaw IV secara baik dan benar dapat meningkatkan hasil belajar PKn siswa kelas X IPA.4 SMA Negeri 9 Pekanbaru tahun ajaran 2017/2018.

\section{KESIMPULAN}

1. Sebelum diterapkannya Model Pembelajaran Kooperatif Tipe Jigsaw IV diketahui bahwa siswa yang memperoleh nilai dibawah kriteria ketuntasan minimal (KKM) sebesar $52,6 \%$, pada siklus pertama setelah diterapkannya Model Pembelajaran Kooperatif Tipe Jigsaw IV, siswa yang belum tuntas sebesar 24\% atau masih terdapat 9 orang siswa yang belum mencapai ketuntasan klasikal yakni nilai 75.

2. Pada siklus kedua setelah diadakan perbaikan Model Pembelajaran Kooperatif Tipe Jigsaw IV , siswa yang belum tuntas sebesar 16\% atau hanya terdapat 6 orang siswa yang belum 
mencapai ketuntasan klasikal yakni nilai 75 seperti yang telah ditetapkan di SMA Negeri 9 Pekanbaru. Sedangkan siswa yang telah mencapai nilai kriteria ketuntasan minimal (KKM) mengalami peningkatan terlihat dari data sebelumnya sebesar $76 \%$ atau 29 orang siswa menjadi $84 \%$ atau 32 orang siswa. Oleh karena itu, dapat dikatakan bahwa hasil belajar mata pelajaran PKn pada siklus kedua ini telah mencapai ketuntasan kelas dengan rata-rata keseluruhan pada siklus 2 mencapai 84> KKM.

3. Berdasarkan hasil analisis dan pembahasan seperti disampaikankan pada bab IV dapat disimpulkan bahwa penerapan Model Kooperatif Tipe Jigsaw IVdapat meningkatkan hasil belajar PKn pada siswa kelas X IPA.4 SMA Negeri 9 Pekanbaru tahun ajaran 2016-2017. Keberhasilan ini disebabkan dengan menggunakan Model Kooperatif Tipe Jigsaw IV aktivitas siswa menjadi lebih meningkat dan terjadi interaksi antara siswa dan guru serta siswa dengan siswa. Dengan demikian siswa cenderung positif dalam mengikuti proses belajar mengajar yang diberikan oleh guru. Dengan kondisi tersebut maka tingkat penerimaan siswa akan meningkat dan pada gilirannya dapat meningkatkan hasil belajarnya.

\section{SARAN}

Bertolak dari kesimpulan dan pembahasan hasil penelitian di atas, berkaitan dengan penerapan yang telah dilaksanakan, peneliti mengajukan beberapa saran, yaitu:
1. Guru sebagai pelaksana pembelajaran hendaknya mempelajari berbagai metode agar dapat meningkatkan hasil belajar siswa, khususnya Model Kooperatif Tipe Jigsaw IV.

2. Agar pelaksanaan penerapan Model Pembelajaran Kooperatif Tipe Jigsaw IV tersebut dapat berjalan dengan baik, maka sebaiknya guru lebih sering menerapkannya.

\section{DAFTAR PUSTAKA}

Gimin, Dkk. 2005.Pedoman Penulisan Karya Ilmiah Mahasiswa. FKIP.UNRI.

http://www.eric.ed.gov/ERICDocs/data/eri cdocs2sq1/content_storage_01/00000 19b/80/16/9f/be.pdf).

Isjoni. 2007.Pembelajaran Visioner. Jakarta. Pustaka pelajar

Kunandar.2007. Guru Profesional Implementasi Kurikulum Tingkat Satuan Pendidikan (KTSP) Dan Persiapan Menghadapi Sertifikasi Guru. PT. Raja Grafindo Persada, Jakarta.

Muhibbin Syah. 2007. Psikolgi Belajar. Jakarta. Rajawali pers..

Oemar Hamalik. 2004. Proses Belajar Mengajar. Jakarta. Bumi aksara

Sardiman, A.M.2004. Interaksi dan Motivasi Belajar Mengajar. Jakarta. Rajawali, Pers

Slavin, Robert E, 2008, Cooperative learning Teori, Riset dan Praktis.Bandung Nusa Media.

Slameto. 2003. Belajar dan faktor-faktor yang mempengaruhinya. Jakarta. 
